\title{
The role of work-related needs in the relationship between job crafting, burnout and engagement
}

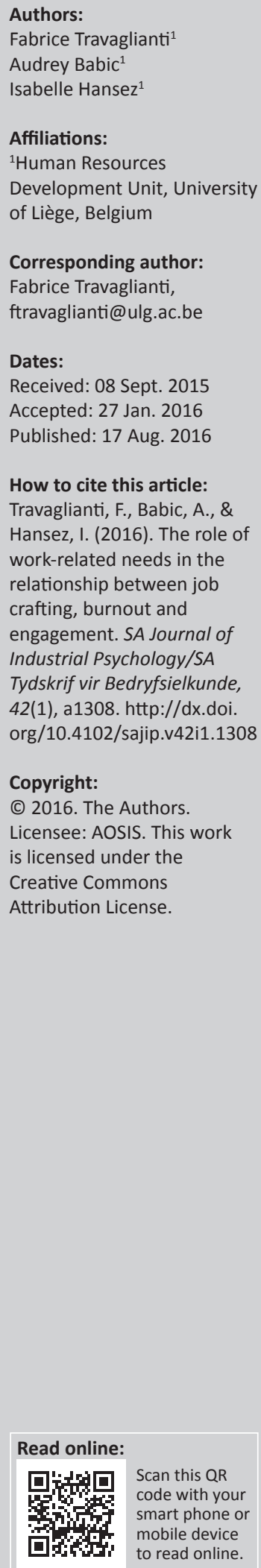

Orientation: Knowing that it is imperative to better understand the antecedents and consequences of needs-supplies fit, the present research had two main objectives. Firstly we wanted to extend our knowledge about traditional psychological needs, for example highlighted through the Self-Determination Theory, by presenting more specific work-related needs. Secondly, following the new directions of organisational fit theories, we wanted to better understand how individuals make sense of fit.

Research purpose: The purpose of this study is to propose more specific work-related needs in terms of employment quality and to test job crafting as an antecedent of needs-supplies fit (NS fit). We tested the double mediating role of NS fit (i.e. specific: based on more specific work-related needs, and general: based on global job perceptions) between job crafting and individual outcomes namely burnout and work engagement.

Motivation for the study: By taking into account more specific work-related needs, this study aimed to add more specific information to better help predict well-being at work. Moreover, the present research responds to the need to better understand how individuals make sense of fit.

Research design, approach, and method: Data were collected in a Belgian Public Federal Service $(N=1500)$. Our research model was tested using Structural Equation Modelling with Mplus.

Main findings: Results show, (1) that specific NS fit perception was positively related to a global NS fit perception and (2) the partial mediating role (specific and general) of NS fit between job crafting and burnout and work engagement.

Practical/managerial implications: Managers should encourage crafting behaviours and should know their team and that team's specific needs.

Contribution/added-value: By taking into account more specific work-related needs, our study suggests that needs-supplies may have more than one dimension. Moreover, it shows that job crafting is a way to increase NS fit.

\section{Introduction}

According to the person-environment fit (PE fit) theory, 'the misfit between the person and the environment may produce psychological, physiological, and behavioural strains and can take two different forms: (1) the extent to which the demands and requirements of the environment match the skills and abilities of the person and (2) the extent to which the rewards and supplies provided by the environment match the needs and preferences of the person' (Edwards \& Van Harrison, 1993, p. 628). In this context, because individuals who can choose a working environment in congruence with their personal characteristics will experience more positive work-related outcomes, it is not surprising that PE fit has become one of the most studied concepts in work and organisational psychology (Kristof-Brown, Zimmerman \& Johnson, 2005). Following Kristof-Brown et al. (2005), it is now recognised that PE fit is a multidimensional concept which includes person-organisation fit (PO fit), person-group fit (PG fit), personsupervisor fit (PS fit), person-vocation fit (PV fit), and person-job fit (PJ fit). Person-job fit can also be divided into two conceptualisations: demands-abilities fit (DA fit) and needs-supplies fit (NS fit). Because it is important to further investigate the antecedents and the consequences of NS fit (Kristof-Brown \& Billsbery, 2013), and because 'NS fit may be the most important type of fit from an employee point of view' (Cable \& De Rue, 2002, p. 875), we have chosen to focus on this. 


\section{Research purpose and objectives}

This study has two main objectives. Firstly, in order to extend our knowledge about traditional psychological needs, as for example the three fundamental needs (i.e. competence, autonomy, and relatedness) highlighted by the SelfDetermination Theory (SDT; Deci \& Ryan, 2000), we wanted to propose more specific work-related needs in terms of employment quality. To better understand the meaning of needs at work and to ascertain the importance of workrelated needs fulfilment, we followed a subjectivist approach (i.e. a focus on employees' needs fulfilment; Brown, Charlwood, Forde \& Spencer, 2007). Following Burchell, Sehnbruch, Piasna and Agloni (2013), this is 'conceptually more advanced than previous attempts to measure the quality of employment' (Burchell et al., 2013, p. 8). Secondly, following the new directions of organisational fit theories (Kristof-Brown \& Billsbery, 2013), we wanted to better understand how individuals make sense of fit. To this end, and because it represents proactive behaviour through which people take initiative to make changes in their jobs (Yu, 2013), we tested job crafting (JC) as an antecedent of NS fit. Moreover, because many studies have already highlighted the positive consequences of JC on individual outcomes (e.g. Tims \& Bakker, 2010; Tims, Bakker \& Derks, 2013), the present research tries to expand our understanding about the underlying mechanisms of this relationship. Thus we tested the double mediating role of specific NS fit (i.e. based on more specific work-related needs) and global NS fit (i.e. based on global job perceptions) between JC and two individual outcomes, namely burnout (BO) and work engagement (WE).

\section{Literature review}

Regarding our two objectives, this paper will firstly present NS fit theory particularly in terms of the importance of workrelated needs for employment quality; we then present JC and the link between NS fit, JC, and individual outcomes.

\section{Needs-supplies fit and specific work-related needs}

NS fit refers to the congruence between needs on one side and job characteristics on the other (Kristof-Brown et al., 2005). NS fit is illustrated by the fit between needs and supplies that gives a general perception of needs fulfilment (Edwards \& Shipp, 2007). For Kämpfe and Mitte (2009), neither the individual's current state, nor his or her goals are sufficient to predict well-being; it is more a question of the discrepancies between these. According to this view, the wider the gap, the greater the likelihood of negative consequences on mental and physical well-being; conversely the greater the match, the greater the likelihood of positive consequences such as engagement at work and job satisfaction (e.g. Dylag, Jaworek, Karwowski, Kozusznik \& Marek, 2013; Edwards \& Shipp, 2007; Van Zyl, Deacon \& Rothman, 2010).

Prior studies have already highlighted the positive consequences of psychological needs fulfilment on both individual and organisational outcomes such as job satisfaction, job strain, or organisational identification (see Kristof-Brown et al., 2005 for a meta-analysis) and many theories conceptualise how psychological needs fulfilment is related to well-being at work and positive employee attitudes. Firstly, following the PE fit theory of stress (Edwards, Caplan \& Harrison, 1998), NS fit is an important mechanism for understanding how the relation between the individual and the environment has an impact on mental and physical well-being. Indeed, according to this theory, job stress is defined as the misfit between subjective needs and supplies; it is the 'critical mechanism through which the person and environment jointly influence mental and physical wellbeing' (Edwards \& Shipp, 2007, p. 24). Secondly, cybernetic theories of stress (Cumming \& Cooper, 1979) advance that the proximal cause of well-being is the perceived misfit between actual and desired states. In this way, 'needssupplies misfit can be interpreted as stress when needs and supplies are both subjective and supplies fall short of needs' (Edwards \& Shipp, 2007, p. 226). Finally, because of the importance of psychological needs in well-being enhancement, SDT could also explain how perceived NS fit is associated with positive attitudes and behaviours (e.g. Greguras \& Diefendorff, 2009). According to SDT, if individuals are able to satisfy their three innate psychological needs (autonomy, competence, and relatedness), they will develop their fullest potential and thus function optimally (Deci \& Ryan, 2000). As already stated above, we wanted this paper to extend our knowledge about these three psychological needs by presenting more specific workrelated needs in terms of employment quality.

Because of the many conceptualisations of employment quality, it is difficult to find a common definition of 'a good job' (Burchell et al., 2013). Nevertheless, some academics and certain institutions such as the International Labour Organisation (ILO) and the EU have attempted to develop a range of indicators to define what is termed 'a good job'. For example, the ILO, through its concept 'Decent Work' (1999), proposes 10 indicators of employment quality such as development opportunities, health, safety, and work-home balance. In their work for the European Parliament, Muñoz de Bustillo, Fernandez-Macias, Anton and Esteve (2009) have also proposed 20 job quality indicators including wages, working time, flexibility, security, and autonomy. At the academic level, several authors have developed indicators of employment quality in order to help with the definition and measurement of 'a good job' (see Körner, Puch \& Wingerter, 2009; Van Aerden, Levecque \& Vanroelen, 2015). These authors have highlighted a broad set of indicators of employment quality including work organisation; wages and payment system; security and flexibility; skills and development; workers' rights and social protection; employability opportunities; safety; ethics in employment; and the work-life balance. Based on these classifications, we propose a synthetic overview of these sources that define employment quality (Table 1). Consequently, in this study, 'a good job', with high employment quality is defined on the 
TABLE 1: Synthesis of the employment quality indicators.

\begin{tabular}{ll}
\hline Number & Employment quality's indicators \\
\hline 1 & Job content \\
2 & Work-home balance \\
3 & Working time \\
4 & Working space \\
5 & Wages \\
6 & Training \\
7 & Employability \\
8 & Contract stability \\
9 & Social protection \\
10 & Work place security \\
\hline
\end{tabular}

Source: Travaglianti, F., Orianne, J.F., Pichault, F., \& Hansez I. (2015). Construction d'une méthodologie exploratoire concernant les besoins des travailleurs: l'exemple des besoins de fexibilité au travil et de sécurité d'emploi des travailleurs à contrat permasesoins de Internationale de Psychosociologie et de Gestion des Comportements Organisationnels, 21(52), 147-162

basis of 10 indicators, (1) job content, (2) work-home balance, (3) working time, (4) working space, (5) wages, (6) training, (7) employability, (8) contract stability, (9) social protection and (10) work place security.

On this basis, and in order to understand the importance of workers' needs in the context of employment quality, we suggest following a subjectivist approach. This approach focuses on specific work-related needs and their perceived fulfilment as the basis for the association between high quality jobs with positive job attitudes (e.g. Brown et al., 2007). Körner et al. (2009) have already proposed seven employment quality indicators following a basic needs approach (Maslow, 1958) as a theoretical foundation. In their work, Körner et al. (2009) argued that individuals will perceive high employment quality if, for example, their needs for safety, income, security, and skills development are fulfilled. According to these authors, it thus seems important to take work-related needs into account to understand how high quality jobs may result in positive job attitudes.

Moreover, based on more specific work-related needs, and because existing NS fit scales assess NS fit through a global fit perception between needs and general job characteristics (e.g. Cable \& De Rue, 2002), we further suggest that perceived global NS fit (i.e. based on a global job perception) may result from a specific perceived NS fit (i.e. based on more specific work-related needs). In other words, we propose that individuals may come to an overall fit perception after adding together specific dimensions of fit (Seong \& Kristof-Brown, 2012). Such a suggestion has already been proposed and verified in a previous study (Travaglianti, Babic, Pepermans \& Hansez, in press) using information integration theory (IIT; Anderson, 1962) to explain this relationship. Indeed, following IIT, individuals integrate information from a number of sources in order to finally make an overall judgement. IIT is thus a general theory explaining how, using 'cognitive algebra', an individual combines several items of information to produce a response. According to Anderson's theory, there are three main steps in the impression formation process. The first is the valuation function, in which individuals map each piece of information on a subjective scale. The second is the integration function using added (i.e. adding stimulus values) or averaged (i.e. averaging stimulus value) cognitive algebra
(Anderson, 1962) to combine the subjective values of information. The third is the response production function through which the internal impression is translated into a general response.

Thus, following the IIT (Anderson, 1962), our first hypothesis is:

H1: A specific work-related NS fit perception in terms of employment quality is positively associated with a global NS fit perception.

\section{Job crafting}

As a second objective, and because of 'the lack of research treating PE fit as an outcome' (Yu, 2013), we tested JC as an antecedent of NS fit. This follows from Yu's PE fit model (2009) - in which JC can describe how individuals are motivated to fit with their environment.

JC was initially defined by Wrzesniewski and Dutton (2001) as 'the physical and cognitive changes individuals make in the task or relational boundaries of their work' (p. 179). According to this definition, employees engaged in crafting behaviours are motivated to alter the meanings of their work by modifying, for example, its design or its social environment. Accordingly, individuals who engage in these proactive behaviours (i.e. anticipatory behaviours aimed at bringing aboutchange to individuals themselves and their environment; Grant \& Ashford, 2008) may proactively change different aspects of their jobs, such as their tasks (i.e. the amount or the content of tasks), their relationships at work (i.e. the amount or the intensity of contact with their colleagues), or their cognitions about their job (i.e. enhancing the meaning of their jobs) (Tims, Bakker \& Derks, 2012). Individuals adopt such proactive behaviours in order to match with their ability and needs and thus to increase the fit between themselves and their environment (Black \& Ashord, 1995).

Recently, to include a larger set of job characteristics that employees may modify, several authors (e.g. Tims et al., 2012; Tims, Bakker, Derks \& Van Rhenen, 2013) define JC using the job demands-resources (JD-R) model (Demerouti, Bakker, Nachreiner \& Schaufeli, 2001). In the JD-R model, job characteristics are divided into two categories: job demands, defined as the physical, social or organizational aspects of the job that require sustained physical or mental effort and are therefore associated with certain physiological and psychological costs' (Demerouti et al., 2001, p. 501) and job resources, that refer to those aspects of the job that may be functional in achieving work goals, may reduce job demands and stimulate individuals' personal growth and development (Demerouti et al., 2001). In this way, and based on the JD-R model, JC has been defined by Tims et al. (2012) as 'the changes that employees may make to balance their job demands and job resources with their personal abilities and needs' (p. 174).

Many studies have already explored the positive consequences of JC (e.g. Tims \& Bakker, 2010; Tims, Bakker \& Derks, 2013) advancing that people who engage in crafting behaviours are more engaged in their job, more satisfied with their job and less likely to develop BO syndrome. These 
authors explain this process through $\mathrm{JC}^{\prime} \mathrm{s}$ three main dimensions (i.e. increasing job resources, increasing challenging job demands, and decreasing hindering job demands). More precisely, individuals may proactively increase their resources and challenging job demands and decrease their hindering job demands, in order to increase their personal growth and job satisfaction (Tims et al., 2012).

Regarding the relationship between fit perceptions and JC, even if a few studies have already shown that JC is an antecedent of PJ fit (e.g. Lu, Wang, Lu, Du \& Bakker, 2014), none of these have focused on the role of perceived NS fit between JC and individual outcomes. Following the JC definition based on the JD-R model (Demerouti et al., 2001), and knowing that job demands and job resources are two important work environment characteristics to consider to explain $\mathrm{BO}$ and $\mathrm{WE}$, it seems important to further investigate which mechanisms underlie the relationship between JC and these specific individual outcomes. Thus, in the present study, we argue that specific NS fit and global NS fit play a mediating role between JC and individual outcomes, namely $\mathrm{BO}$ and WE. To define BO, we have decided to follow the Maslach, Jackson and Leiter (1996) definition. According to these authors, burnout refers to a syndrome of exhaustion, cynicism, and reduced professional efficacy (Maslach et al., 1996). Regarding WE, we have decided to define it as 'an affective-motivational, work-related state of fulfilment that is characterized by vigour, dedication and absorption' (Schaufeli \& Bakker, 2004, p. 95).

In line with the theoretical background developed in this paper, we expect that workers engaged in JC behaviours will proactively modify their job to increase the fit between their specific work-related needs and their currentjob characteristics. This will therefore be associated with an increase of their global NS fit perception (i.e. based on global job perception), which, in turn, will increase WE and decrease BO. In view of these assumptions, our second and third hypotheses are:

H2: There is a double mediation of specific needs-supplies fit and global needs-supplies between job crafting and burnout.

H3: There is a double mediation of specific needs-supplies fit and global needs-supplies between job crafting and work engagement.

Figure 1 summarises our research model in view of our three hypotheses.

\section{Research design \\ Research method}

\section{Research participants}

Our sample is made up of workers from a Belgian Federal Public Service. For this study, we randomly selected 1500 respondents from a larger dataset. ${ }^{1}$ In this organisation, there

1.The original dataset was composed of 7016 data (response rate $=25 \%$ ). This low respons A (the le rest his duch A (the lowe thien, because of the multiple objectives of our research project, 1500 to e-mails. Then, because of the multiple objectives of our research project, 1500 data were randomly selected for the present study. This allowed us to undertake other analyses on the remaining dataset.

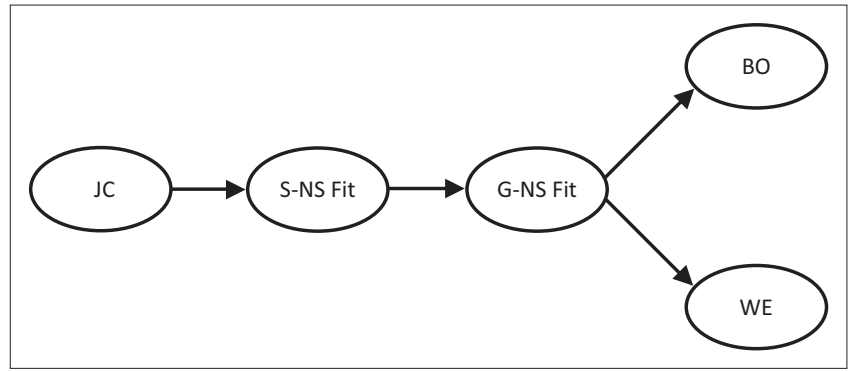

JC, job crafting; S-NS Fit, specific needs-supplies fit; G-NS Fit, global needs-supplies fit; BO, burnout; WE, work engagement.

FIGURE 1: Hypothesised model.

were three different levels of professional status [from lowest (A) to highest (C)]: level A (26.4\%), B (54.4\%), and C (18.7\%), with $0.5 \%$ unknown. These levels are comparable to the traditional differentiations within a traditional workforce: blue-collar, clerical, and managerial. The majority of respondents (85\%) are male and Dutch speaking (61.4\%) and the average age of the sample is 44 years $(\mathrm{SD}=8.5)$.

\section{Measuring instruments}

Unless otherwise specified, the questionnaires were originally in English. We followed the back-translation procedure to propose versions in French and Dutch.

Job crafting (JC): was measured with the four dimensions of the Job Crafting Scale developed by Tims et al. (2012; e.g. 'I try to develop my capacities') and using a five-point frequency scale ranging from 1 (never) to 5 (often). This questionnaire is made up of four main dimensions (increasing structural job resources, decreasing hindering job demands, increasing social job resources, and increasing challenging job demands). Tims et al. (2012) reported that the four dimensions had good reliability (Cronbach's alphas were all above 0.70 and ranged from 0.75 to 0.82 ).

Specific needs-supplies fit (S-NS Fit): was measured with a questionnaire created for the purpose of this research (see Travaglianti et al., in press) and focused on employment quality indicators (Table 1). It comprises 37 items distributed over 12 work-related needs factors, namely the need for a challenging job (three items, $\alpha=0.72$ ), work-family balance (three items, $\alpha=0.83$ ), a clear time schedule (three items, $\alpha=0.69$ ), work flexibility (three items, $\alpha=0.85$ ), additional rewards (three items, $\alpha=0.72$ ), regular financial rewards (three items, $\alpha=0.82$ ), personal development opportunities (three items, $\alpha=0.91$ ), employability (three items, $\alpha=0.78$ ), job security (three items, $\alpha=0.86$ ), social protection (three items, $\alpha=0.69$ ), a comfortable work environment (three items, $\alpha=0.84$ ), and fairness and recognition from the supervisor (four items, $\alpha=0.88$ ) (see Table 2 for sample items of each dimension and Appendix 1 for the overall questionnaire). The questionnaire was originally developed in French and we followed standard back-translation procedures to present a Dutch version. For each item, participants were asked to indicate their ideal state as compared to their present state on a seven-point scale from -3 
TABLE 2: Item examples for each specific needs-supplies fit dimension

\begin{tabular}{|c|c|c|}
\hline Number & Individual needs & Item examples \\
\hline 1 & Challenging job & Do a stimulating job, be autonomous \\
\hline 2 & Work-family balance & $\begin{array}{l}\text { Balance my private and professional life, give } \\
\text { priority to my private life }\end{array}$ \\
\hline 3 & Clear time schedule & $\begin{array}{l}\text { Have predictable work schedule, choose my } \\
\text { working hours }\end{array}$ \\
\hline 4 & Work flexibility & Work from home, distance working \\
\hline 5 & Additional rewards & $\begin{array}{l}\text { Receive an individual performance bonus, extras } \\
\text { benefits }\end{array}$ \\
\hline 6 & $\begin{array}{l}\text { Regular financial } \\
\text { rewards }\end{array}$ & $\begin{array}{l}\text { Receive a fixed monthly income, enough income } \\
\text { to cover needs }\end{array}$ \\
\hline 7 & $\begin{array}{l}\text { Personal development } \\
\text { opportunities }\end{array}$ & $\begin{array}{l}\text { Follow training to extend my skills, to progress in } \\
\text { my career }\end{array}$ \\
\hline 8 & Employability & $\begin{array}{l}\text { Work in a successful company, broaden my } \\
\text { chances of getting another job }\end{array}$ \\
\hline 9 & Job security & $\begin{array}{l}\text { Have a stable work contract, enjoy stable } \\
\text { employment }\end{array}$ \\
\hline 10 & Social protection & $\begin{array}{l}\text { Be supported by trade union, know my social } \\
\text { rights }\end{array}$ \\
\hline 11 & $\begin{array}{l}\text { Comfortable work } \\
\text { environment }\end{array}$ & $\begin{array}{l}\text { Have a good working equipment, acceptable } \\
\text { physical conditions }\end{array}$ \\
\hline 12 & $\begin{array}{l}\text { Fairness and } \\
\text { recognition from } \\
\text { supervisor }\end{array}$ & $\begin{array}{l}\text { Be recognised by superiors, work in a positive } \\
\text { atmosphere, be treated honestly and with respect }\end{array}$ \\
\hline
\end{tabular}

Note: Answer format: 'Ideally, I would like to...'

(I would like much less than now) to +3 (I would like much more than now), with 0 (I am satisfied with my current state) as the middle value.

As the main aim of this paper is to focus on the importance of fit and not on its valence (i.e. positive or negative fit), we used the absolute values of the original scale (Warr \& Inceoglu, 2012). We first took the absolute value of this response scale from 0 (no discrepancy $=$ fit, i.e. satisfied with current state) to 3 (high perceived discrepancy, irrespective of its being negative or positive). In order to increase comprehensibility, we then reversed these scores so that a high value represented optimal fit, and a low value represented misfit (either over-fit or under-fit). See Appendix 2 for information regarding the questionnaire's development.

Global needs-supplies fit (G-NS Fit): was assessed using the three-item scale developed by Cable and DeRue (2002; e.g. 'There is a good fit between what my job offers me and what I am looking for in a job'). A five-point Likert scale ranging from 1 (totally disagree) to 5 (totally agree) was used. Previous research has shown good Cronbach's alphas for these three items (between 0.89 and 0.93; see Cable \& DeRue, 2002).

Work engagement (WE): was measured on a seven-point frequency scale ranging from one (never) to seven (often) with the nine items of the Utrecht Work Engagement Scale (UWES-9; Schaufeli, Bakker \& Salanova, 2006; e.g. 'At my work, I feel bursting with energy'). The UWES-9 items scale is made up of three main dimensions (three items for vigour, three items for dedication, and three items for absorption) and previous research (see Schaufeli et al., 2006) has shown good overall instrument reliability (Cronbach's alpha ranging from 0.85 to 0.92 ) as well as good subdimensions reliability (vigour $=0.77$; dedication $=0.85$, and absorption $=0.78$ ).
Burnout (BO): was assessed with the Oldenburg Burnout Inventory (OLBI; Demerouti, Bakker, Vardakou \& Kantas, 2003). Even if BO has been defined as consisting of three dimensions (i.e. exhaustion, cynicism, and reduced professional efficacy; Maslach et al. (1996), we decided to use the OLBI instead of the Maslach Burnout Inventory (MBI) to measure BO. Following Demerouti and Bakker (2008) the OLBI overcomes an important psychometric shortcoming of the MBI by including positively and negatively framed items to assess two core dimensions of BO: exhaustion (which can be compared to the exhaustion dimension of the MBI) and disengagement (which can be compared to the cynicism dimension of the MBI). According to Demerouti and Bakker (2008), 'professional efficacy was not included in the OLBI as a separate burnout dimension because it is not considered as a core dimension of burnout '(Demerouti \& Bakker, 2008, p. 5).

This scale is made up of two main dimensions (disengagement and exhaustion), and item examples are: 'I feel more and more engaged in my work', and 'When I work, I usually feel energized'. According to the authors' recommendations and because the OLBI has positive and negative stated attributes, some of the items' scores were reversed so that a high value represented higher level of BO. Demerouti, Mostert and Bakker (2010) reported that the two dimensions of the OLBI scale both had a good reliability ( 0.69 for disengagement and 0.74 for exhaustion). Good reliability was been observed for the overall questionnaire (Cronbach's alpha $=0.84$; Demerouti et al., 2003). A four-point Likert scale ranging from 1 (totally disagree) to 4 (totally agree) was used.

Covariates: based on the full partial method recommended by Little (2013), we accounted for the influence of covariates by specifying paths from all socio-demographic variables to all endogenous and exogenous variables. After running this initial model, we removed the non-significant effects. Thus, we controlled statistically for language, gender, age, and status. Following Muthén and Muthén (1998-2014), because language and gender are nominal variables, they were dummy-coded. This option is used to specify that the variable (language for example) is a binary variable. Language is thus a treatment dummy variable where zero represents the control group (or the most representative group, in this study: Dutch = coded 0) and one (1) represents the treatment group (or the less representative group, in this study: French = coded 1). Regarding age and status, these variables can be considered as ordinal because there is a clear rank from low to high. These variables have already been found to be correlated with JC (e.g. Berg, Wrzesniewski \& Dutton, 2010), NS fit (e.g. Krumm, Grube \& Hertel, 2013), BO (e.g. Ahola, Honkonen, Virtanen, Aromaa \& Lönnqvist, 2008), and WE (e.g. Langelaan, Bakker, Van Doornen \& Schaufeli, 2006).

\section{Research procedure and ethical consideration}

Data were collected online through an electronic link to the survey included in an e-mail explaining the purpose of the study and emphasising the confidentiality of the responses 
(anonymous participation). The researchers also outlined the roles and responsibilities of all the parties involved.

Prior to launching the survey, the present study and its design were presented for approval to the ethical committee of the faculty of psychology of the researchers' university. The final decision of the ethical committee was positive suggesting that the present study fulfils all the ethical rules regarding the methodological design.

\section{Statistical analysis}

Our research model was tested using Structural Equation Modelling (SEM) (Mplus 7.11, Muthén \& Muthén, 1998-2014). Following Kline (2011), the model's goodness-of-fit was evaluated with absolute and relative indices. As suggested by this author, the absolute goodness-of-fit were: the root mean square error of approximation (RMSEA; Steiger \& Lind, 1980) and the standardised root mean square residual (SRMR; Hu \& Bentler, 1999). The relative index tested was: the comparative fit index (CFI; Bentler, 1990). According to Kline (2011), a RMSEA index smaller than 0.08, an SRMR smaller than 0.10, and a CFI value greater than 0.90 indicate a good fit.

Data were then analysed following a two-stage process suggested by Anderson and Gerbing (1988). Firstly, we assessed the measurement model through a series of confirmatory factor analyses to ensure that the constructs examined in our study were independent. Secondly, we proceeded with the assessment of the hypothesised structural relationships among latent variables. For this second stage, to reduce the number of parameters to be estimated, we used parcelling strategy (Little, Rhemtulla, Gibson \& Schoemann, 2013). We thus reduced to three the number of indicators for: S-NS Fit, G-NS Fit, JC, WE, and BO, using the balancing technique. Using this technique, we constructed indicators by combining the items with the highest and lowest loadings (Little, Cunningham, Shahar \& Widaman, 2002). Practically, the item with the highest loading is paired with the item with the lowest loading. The next highest and next lowest items' loadings are paired in the second parcel, etc. In this way, an item with a high loading would provide strong support for the construct to match with a weaker item (Little et al., 2013). This balancing technique allowed us to, (1) limit the number of parameters to be estimated (Landis, Beal \& Tesluk, 2000), (2) maintain the robustness of the analysis and preserve common construct variance while minimising unrelated specific variance (Little et al., 2002), and (3) enhance the items' reliability (Little et al., 2013). Moreover, these authors also advance that using parcelling strategy can significantly improve model convergence and model stability. In this way, and regarding the above comments, we believe that parcelling is an important way to reinforce model stability and model fit to the data even with large sample size.

According to several authors' recommendations (e.g. Hayes, 2009), we used the bootstrapping method to test the indirect effects. Indeed, these authors suggested using the bootstrapping technique for studying relations in mediation models, instead of using the traditional Sobel test that presents some limitations. The method was set at 5000 draws (Hayes, 2009). The confidence interval was set at 95\%. When zero is not in the $95 \%$ confidence level, we can conclude that the indirect effect is significant.

Regarding the missing values, we used a full information maximum likelihood approach (FIML) with maximum likelihood (ML) as a normal estimation method. Therefore, all available information in the data set was used to estimate the individual log likelihood functions.

\section{Results \\ Confirmatory factor analyses}

Firstly, we examined the fit of our hypothesised five-factor measurement model (i.e. JC, S-NS Fit, G-NS Fit, BO, and WE). The results indicate that this hypothesised measurement model fit the data reasonably well $\left(\chi^{2}(\mathrm{df})=336.83(80)\right.$, $p<0.001, \mathrm{CFI}=0.98, \mathrm{SRMR}=0.04, \mathrm{RMSEA}=0.05)$.

Starting from this five-factor model, we tested a series of more constrained measurement models to ensure that our constructs were independent (Anderson \& Gerbing, 1988), (1) four-factor model (S-NS, G-NS = 1 factor), (2) four-factor model (BO, WE = 1 factor), (3) four-factor model (JC, BO = 1 factor), (4) four-factor model (JC, WE $=1$ factor), (5) threefactor model (JC, BO, WE = 1 factor), (6) two-factor model (G-NS, JC, BO, WE = 1 factor), and (7) one-factor model (all the variables as a single-factor). Chi-square difference tests were then used to compare the fit of each of these nested models with that of the five-factor model (Bentler \& Bonett, $1980)$. The significance of the chi-square differences $(p<0.05)$ suggests that the five-factor model is superior to the other compared models.

Results of these confirmatory factor analyses indicate that the five-factor model was significantly superior to all alternative models. Consequently, we treated these five constructs as independent from each other in subsequent analyses. Table 3 displays fit indices of these alternative models.

\section{Relationships among variables}

Means, standard deviations, Cronbach's alphas, and correlations among variables are presented in Table 4. As presented in Table 4, the reliability of our scales is good with values greater than 0.7 .

\section{Test of the measurement models}

In order to suggest partial mediation instead of total mediation, we compared the fit of our hypothesised model (Figure 1) with a series of alternative models. This was done to assess whether our hypothesised model offered the best depiction of our data. We then successively added direct theoretically plausible paths among our latent variables (Table 5): the first path between G-NS Fit and JC (alternative model 1), the second between S-NS Fit and BO (alternative 
TABLE 3: Confirmatory factor analysis fit indices for measurement model $(N=1500)$

\begin{tabular}{|c|c|c|c|c|c|c|}
\hline Model & $\chi^{2}$ & $d f$ & $\Delta \chi^{2}(\Delta d f)$ & CFI & SRMR & RMSEA \\
\hline Five-factor model & 336.83 & 80 & - & 0.98 & 0.04 & 0.05 \\
\hline Four-factor model (S-NS, G-NS = 1 factor) & 817.29 & 84 & $480.46(4)^{* * *}$ & 0.94 & 0.06 & 0.08 \\
\hline Four-factor model (BO, WE = 1 factor) & 553.65 & 84 & $216.82(4)^{* * *}$ & 0.96 & 0.05 & 0.06 \\
\hline Four-factor model (JC, BO = 1 factor) & 1429.96 & 84 & $1093.13(4) * * *$ & 0.89 & 0.15 & 0.10 \\
\hline Four-factor model (JC, WE = 1 factor) & 2500.84 & 84 & $2164.01(4)^{* * *}$ & 0.80 & 0.09 & 0.14 \\
\hline Three-factor model (JC, BO, WE = 1 factor) & 2739.07 & 87 & $2402.24(7)^{* * *}$ & 0.78 & 0.10 & 0.14 \\
\hline Two-factor model (G-NS, JC, BO, WE = 1 factor) & 4617.56 & 89 & $4280.73(9)^{* * *}$ & 0.62 & 0.13 & 0.18 \\
\hline One-factor model & 5020.09 & 90 & $4683.26(10)^{* * *}$ & 0.59 & 0.13 & 0.19 \\
\hline
\end{tabular}

S-NS, specific needs-supplies fit; G-NS, global needs-supplies fit; JC, job crafting; BO, burnout; WE, work engagement; $\chi^{2}$, Chi-square; $d f$, degree of freedom; CFI, comparative fit index; SRMR, standardised root mean square residual; RMSEA, root mean square error of approximation.

$*, p<0.05 ; * *, p<0.01 ; * *, p<0.001$

TABLE 4: Descriptive statistics and inter-correlations among variables $(N=1500)$.

\begin{tabular}{|c|c|c|c|c|c|c|c|c|c|c|c|c|c|}
\hline Variables & Minimum & Maximum & $M$ & $S D$ & 1 & 2 & 3 & 4 & 5 & 6 & 7 & 8 & 9 \\
\hline 1. Language & - & - & - & - & - & - & - & - & - & - & - & - & - \\
\hline 2. Gender & - & - & - & - & -0.03 & - & - & - & - & - & - & - & - \\
\hline 3. Age & 19 & 64 & 44.2 & 8.52 & 0.02 & -0.07 & - & - & - & - & - & - & - \\
\hline 4. Status & - & - & - & - & -0.01 & -0.03 & $-0.17 * * *$ & - & - & - & - & - & - \\
\hline 5. S-NS Fit & 0 & 3 & 2.1 & 0.70 & 0.04 & 0.06 & $0.09 * *$ & $0.09 * *$ & (0.93) & - & - & - & - \\
\hline 6. G-NS Fit & 1 & 5 & 3.4 & 0.88 & -0.01 & 0.06 & $0.09 * *$ & 0.03 & $0.50 * * *$ & $(0.92)$ & - & - & - \\
\hline 7. JC & 1 & 5 & 4.0 & 0.65 & -0.04 & 0.02 & $-0.09 * *$ & $0.10 * *$ & 0.02 & $0.17 * * *$ & $(0.75)$ & - & - \\
\hline 8. WE & 1 & 4 & 4.9 & 1.14 & $0.11 * *$ & -0.02 & $0.11^{* *}$ & -0.01 & $0.28 * * *$ & $0.58^{* * *}$ & $0.39 * * *$ & $(0.88)$ & - \\
\hline 9. $\mathrm{BO}$ & 1 & 7 & 2.2 & 0.51 & 0.03 & 0.02 & $-0.07 *$ & 0.03 & $-0.44 * * *$ & $-0.56 * * *$ & $-0.25 * * *$ & $-0.60 * * *$ & (0.91) \\
\hline
\end{tabular}

Language, Dutch coded 0; French coded 1; Gender, men coded 0; women coded 1; S-NS, Specific Needs-Supplies fit; G-NS, Global Needs-Supplies Fit; JC, Job Crafting; WE, Work Engagement; BO, Burnout.

$*, p<0.05 ; * *, p<0.01 ; * * *, p<0.001$

Note: Cronbach's alphas are provided on the diagonal.

TABLE 5: Fit indices for structural models $(N=1500)$.

\begin{tabular}{|c|c|c|c|c|c|c|c|}
\hline Model & $\chi^{2}$ & $d f$ & $\Delta \chi^{2}(\Delta d f)$ & CFI & SRMR & RMSEA & Model comparison \\
\hline Hypothesised & 729.59 & 133 & - & 0.93 & 0.08 & 0.06 & - \\
\hline Alternative 1: direct path between G-NS and JC & 686.38 & 132 & $43.21(1)^{* * *}$ & 0.94 & 0.06 & 0.06 & Alternative 1 vs Hypothesised \\
\hline Alternative 2: direct path between S-NS and BO & 651.40 & 131 & $34.98(1)^{* * *}$ & 0.95 & 0.06 & 0.06 & Alternative 2 vs Alternative 1 \\
\hline Alternative 3: direct path between S-NS and WE & 650.74 & 130 & $0.66(1) \mathrm{NS}$ & 0.95 & 0.06 & 0.06 & Alternative 3 vs Alternative 2 \\
\hline Alternative 4: direct path between JC and WE & 550.30 & 130 & $101.10(1)^{* * *}$ & 0.95 & 0.05 & 0.05 & Alternative 4 vs Alternative 2 \\
\hline Alternative 5: direct path between $\mathrm{JC}$ and $\mathrm{BO}$ & 495.93 & 129 & $155.47(1)^{* * *}$ & 0.96 & 0.04 & 0.05 & Alternative 5 vs Alternative 4 \\
\hline
\end{tabular}

S-NS, specific needs-supplies fit; G-NS, global needs-supplies fit; JC, job crafting; BO, burnout; WE, work engagement; df, degree of freedom; CFI, comparative fit index; SRMR, standardised root mean square residual; RMSEA, root mean square error of approximation.

$*, p<0.05 ; * *, p<0.01 ; * *, p<0.001$

model 2). As a result of a chi-square difference test (Gonzalez \& Griffin, 2001), alternative model 2 presented a fit that was superior to preceding models. We then added a path from S-NS Fit and WE (alternative model 3), but this model did not have a significantly better fit than alternative model 2 $\left(\Delta \chi^{2}[1]=0.66, p>0.05\right)$.

Then, starting again with alternative model 2, we finally add paths from JC to WE (alternative model 4) and from JC to BO (alternative model 5). As shown in Table 5, the alternative model 5 (Figure 2) presented better fit indices $\left(\chi^{2}[d f]=\right.$ 495.93[129], $p<0.001, \mathrm{CFI}=0.96$, SRMR $=0.04$, RMSEA $=$ $0.05)$ than the previous models. Thus, a model with additional direct links between (1) JC and global NS fit, (2) JC and burnout, (3) JC and WE, and finally (4) specific NS fit and burnout presented better fit indices. The alternative model 5 was thus retained as the best fitting model.

Standardised parameter estimates for the final model are shown in Figure 2. For the sake of clarity, only structural relationships are shown and the effects of the covariates are described in the text. Language was negatively related to JC $(\gamma=-0.07, p<0.01)$ and positively related to WE $(\gamma=0.14$, $p<0.001)$. Gender was significantly related to specific NS fit $(\gamma=0.09 p<0.001)$. Age was positively related to specific NS fit $(\gamma=0.18, p<0.001)$ and negatively to JC $(\gamma=-0.09$, $p<0.001)$. Status was positively related with S-NS Fit $(\gamma=0.09$, $p<0.001)$, JC $(\gamma=0.09, p<0.0001)$, and BU $(\gamma=0.11, p<0.001)$. Controlling for these variables, JC was positively associated with specific NS fit $(\gamma=0.10, p<0.001)$ which, in turn, was positively associated with general NS fit $(\beta=0.65, p<0.001)$; this in turn was negatively associated with $\mathrm{BO}$ and positively associated with WE (respectively, $\beta=-0.41, p<0.001 ; \gamma=0.58$, $p<0.001)$. JC was also directly associated with global NS fit $(\gamma=0.15, p<0.001), \mathrm{BO}(\gamma=-0.25, p<0.001)$, and WE $(\gamma=0.32$, $p<0.001)$. Specific NS fit was directly and negatively associated with $\mathrm{BO}(\gamma=-0.38, p<0.001)$.

\section{Testing the indirect effect}

To examine whether the relationships between (1) JC and BO and (2) JC and WE were mediated by S-NS Fit and G-NS Fit, we used the bootstrapping method (Hayes, 2009). Using this 
TABLE 6: Mediation of the effects of job crafting on burnout and work engagement through S-NS Fit and G-NS Fit.

\begin{tabular}{lccc}
\hline Effects of job crafting & SE & \multicolumn{2}{c}{ Percentile 99\% Cl } \\
\cline { 3 - 4 } & & Lower & Upper \\
\hline Burnout & -0.03 & -0.06 & -0.007 \\
Work engagement & $0.04 \dagger$ & 0.002 & 0.07 \\
\hline
\end{tabular}

$\mathrm{SE}$, standard error; $\mathrm{Cl}$, confidence interval; 1000 bootstrap samples.

$\dagger$, Percentile $95 \% \mathrm{Cl}$.

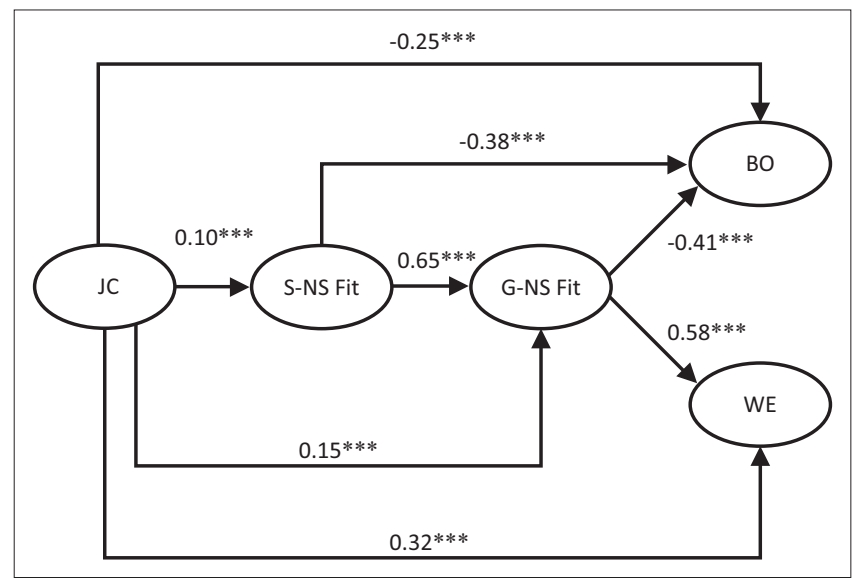

$\chi^{2}(d f)=495.93(129) ; p<0.001 ; \mathrm{CFI}=0.96, \mathrm{SRMR}=0.04, \mathrm{RMSEA}=0.05$.

JC, job crafting; S-NS Fit, specific needs-supplies fit; G-NS Fit, global needs-supplies fit; BO, burnout; WE, work engagement.

$*, p<0.05 ; * *, p<0.01 ; * * *, p<0.001$

FIGURE 2: Alternative model 5: Completely standardised path coefficients.

method and in order to evaluate the total mediating role of S-NS Fit and G-NS Fit, we constructed two-sided biascorrected 95\% confidence intervals (Table 6).

Regarding the indirect effect of JC on BO and WE (via specific and general NS fit), bootstrap analyses indicated that no confidence interval included 0 , highlighting the significance of these indirect effects $(p<0.001)$ (Table 6). Therefore, because JC is directly associated with $\mathrm{BO}$ and WE, NS fit perceptions (specific or general) play a partial mediating role between JC and the outcomes. Thus, our hypotheses $\mathrm{H} 2$ and H3, are partially supported.

\section{Discussion}

\section{Outline of the results}

Because of the importance of continuing to study NS fit and because too little research considers fit perceptions as an outcome (Yu, 2013), the present study has explored two main objectives. Firstly, by taking into account more specific workrelated needs, we wanted to extend our knowledge about traditional psychological needs, for example, as highlighted through the SDT, that individuals have three fundamental needs (autonomy, competence, and relatedness). In this vein, although NS fit seems to be one-dimensional (e.g. Cable \& DeRue, 2002), our study suggests that NS fit may be composed of more than one dimension. Secondly, because it is imperative to better understand how individuals make sense of fit (Kristof-Brown \& Billsbery, 2013), we tested the double mediating role of S-NS Fit (i.e. based on more specific workrelated needs) and G-NS Fit (i.e. based on global job perception) between JC and individual outcomes namely $\mathrm{BO}$ and WE.
Our first hypothesis (H1): 'a specific work-related NS fit perception in terms of employment quality is positively associated with a global NS fit perception', is supported. According to IIT (Anderson, 1962), individuals integrate information from a number of sources before finally making an overall judgement. In the context of our research, workers first judge whether their job characteristics fulfil their specific needs in terms of employment quality before coming to an overall NS fit perception regarding their job in general. In work and organisational psychology, such a differential has already been advanced in organisational justice research. More precisely, Fairness Heuristic Theory (FHT; Lind, 2001) suggests that a global impression of fair treatment (i.e. an overall justice perception) is rapidly formed through a 'judgement phase' using procedural, distributive, and interpersonal justice. Then, these specific elements are aggregated to form a global justice judgement.

Moreover, although NS fit is traditionally seen as a singlefactor concept (e.g. Cable \& De Rue, 2002; Greguras \& Dieffendorf, 2009), the present research highlights that individuals form a specific NS fit perception based on 12 more specific work-related needs in terms of employment quality. Such a result has already been advanced by Seong and Kristof-Brown (2012) regarding the multidimensionality of PG fit. According to these authors, PG fit is a superordinate construct composed of three main dimensions (i.e. valuebased fit, personality-based fit, and ability-based fit) in which each dimension is a reflective indicator of a latent construct. Even if 'the idea of a superordinate fit concept is relatively new' (Seong \& Kristof-Brown, 2012, p. 549), our results about NS fit seem to go in the same direction. NS fit may be a superordinate construct composed of 12 dimensions of workrelated needs.

Our second and third hypotheses (H2): 'There is a double mediation of specific needs-supplies fit and global needssupplies between job crafting and burnout' and (H3): 'There is a double mediation of specific needs-supplies fit and global needs-supplies between job crafting and work engagement', are partially supported. These results suggest two main trends. Firstly, by showing a direct link between JC and the outcomes (i.e. BO and WE), our results suggest that, as a proactive behaviour through which employees are motivated to alter the meanings of their job, JC is associated positively with WE and negatively with BO. These results are in line with previous research (e.g. Tims \& Bakker, 2010; Tims et al., 2013) advancing that when individuals are able to proactively increase their resources and challenging demands and decrease their hindering demands, (in other words, when they are able to craft their job) they are more likely to be engaged in their job and are less likely to be exhausted by it.

Secondly, by testing the double mediating role of S-NS and G-NS Fit perception, and subsequently, JC as an antecedent of NS fit, the present research answers the call of KristofBrown and Billsbery (2013) for more studies on fit antecedents. According to these authors, it has become important to 
undertake additional research to better understand how individuals make sense of fit. In this vein, and in line with Yu's PE fit model (2009), our findings suggest that individuals who can themselves change the task or relational boundaries of their job will create a better place to work, depending on their needs. In other words, workers' ability to craft their job to match with their needs is associated with a better fit perception between their specific work-related needs and their job characteristics. This specific fit perception is then positively related to a global impression of fit with the job in general which, in turn, is associated with a higher level of WE and a lower level of BO. Thus, our study provides empirical evidence of the underlying mechanisms between JC and individual outcomes, but also of the role of JC behaviours in proactively modifying the nature of the job in order to match with workers' needs and desires. Moreover, while the SDT proposes that individuals perceiving their general psychological needs as fulfilled will function optimally (Deci \& Ryan, 2000), the present study suggests that in a work context, work-related needs in terms of employment quality may help to add more specific information to better help predict $\mathrm{BO}$ and WE. Such a result has already been found in a previous study (Travaglianti et al., in press) in which workrelated needs add more specific information to help predict performance.

\section{Practical implications}

Considering that contemporary organisations need employees who are engaged with their work (Bakker, Albrecht \& Leiter, 2011) and because it is ever more important to prevent BO in order to avoid negative consequences such as health problems (e.g. Schaufeli \& Bakker, 2004), our results highlight the importance of JC and work-related needs fulfilment to explain well-being. Indeed, knowing that in Belgium, absenteeism related to mental illness such as $\mathrm{BO}$ and stress increased by about 13\% between 2005 and 2013 (Securex, 2014) and that its related cost represents $3.4 \%$ of GDP (OCDE, 2012), it is an important concern for managers and business leaders. Moreover, from an academic perspective, several authors have also shown the negative consequences of $\mathrm{BO}$ on job performance (e.g. Bakker, Demerouti \& Verbeke, 2004) and the positive effect of WE on job performance (Rich, Lepine \& Crawford, 2010) and on reduced turnover intention (Schaufeli \& Bakker, 2004).

In this way, our results suggest that, as a consequence of a fit between individuals' needs and their job characteristics, 'crafter' workers will be more engaged in their job and less impacted by BO. It thus seems important, firstly, to encourage JC behaviours in order to increase WE and decrease BO. We thus encourage managers to inform their employees about the positive consequences of JC and to create a favourable work environment in which crafting behaviours are possible. Managers should, for example, ensure more job autonomy and increase interactions. In this way, employees may be able to modify their job demands and their job resources to match with their own needs and abilities, in order to increase their well-being at work. Moreover, because JC is also positively related to in-role performance (Tims et al., 2012), organisations may also benefit from the positive consequences of JC.

Secondly, concerning NS fit, our results are also important for practicing managers. Indeed, need-supply fit has been shown to be related to individual outcomes such as BO and engagement but also to more organisational outcomes such as organisational commitment, job performance, or intention to stay (e.g. Kristof-Brown et al., 2005). These results suggest that managers should also focus on work-related needs fulfilment and not only on DA fit in order to foster job performance and well-being at work. From an individual perspective, it is thus important that managers know their team and the team's specific needs in order to motivate team members and avoid BO syndrome. From an organisational perspective, it is important to fulfil workers' needs in order to increase their overall job performance. The 'work-related needs diagnosis' may take place during the annual performance assessment in which managers should evaluate whether workers' specific needs are taken into account in their current job situation. It may also be feasible to create or develop career paths within the organisation and, more specifically, to redirect workers towards jobs that better meet their specific needs.

\section{Limitations and recommendations}

This study is not without limitations. Firstly, we used selfreported data, which may lead to common method bias. Nevertheless, this bias was partially addressed with the results of our confirmatory factor analyses that indicate that a single-factor model showed a poor fit to the data (i.e. Harman's single-factor test; Podsakoff, MacKenzie \& Podsakoff, 2012). Secondly, our research design was crosssectional, which precludes making inferences of causality among the variables. Moreover, a longitudinal design would help us to be sure about the direction of our relationships and about the process underlying the general NS fit perceptions. Then, to be sure that a specific NS fit perception is an antecedent (and not a consequence) of global NS fit perception, it is important to test the direction of this relationship with a longitudinal design. In terms of additional study, it also seems important to better understand the role of coping strategies as moderators in the relationship between NS fit and individual outcomes. Finally, regarding JC, even if several studies (e.g. Tims et al., 2012) show that it is more common to consider the four dimensions of the concept separately, the present study suggests examining JC as a proactive behaviour and considering it as a whole (see Bakker, Tims \& Derks, 2012). Indeed, the main aim of the present research was to better understand whether crafting possibilities lead to an increase of NS fit perception without taking into account the concept's subdimensions.

\section{Acknowledgements}

The research was funded through the ARC grant for Concerted Research Actions, financed by the French Community of Belgium (Wallonia-Brussels Federation). 


\section{Competing interests}

The authors declare that they have no financial or personal relationships which may have inappropriately influenced them in writing this article.

\section{Authors' contributions}

F.T. was the main project leader, A.B. helped with the data collection and I.H. was the supervisor of the project.

\section{References}

Ahola, K., Honkonen, T., Virtanen, M., Aromaa, A., \& Lönnqvist, J. (2008). Burnout in relation to age in the adult working population. Journal of Occupational Health, 50(4), 362-365. http://doi.org/10.1539/joh.M8002

Anderson, J.C., \& Gerbing, D.W. (1988). Structural equation modelling in practice: A review and recommended two-step approach. Psychological Bulletin, 103(3), 411-423. http://dx.doi.org/10.1037/0033-2909.103.3.41

Anderson, N.H. (1962). Application of an additive model to impression formation Science, 138(3542), 817-818. http://dx.doi.org/10.1126/science.138.3542.817

Bakker, A.B., Albrecht, S.L., \& Leiter, M.P. (2011). Key questions regarding work engagement. European Journal of Work and Organizational Psychology, 20(1) 4-28. http://dx.doi.org/10.1080/1359432X.2010.485352

Bakker, A.B., Demerouti, E., \& Verbeke, W. (2004). Using the job demands-resources model to predict burnout and performance. Human Resource Management, 43(1), 83-104. http://dx.doi.org/10.1002/hrm.20004

Bakker, A.B., Tims, M., \& Derks, D. (2012). Proactive personality and job performance: The role of job crafting and work engagement. Human Relations, 65(10), 1359-1378. http://dx.doi.org/10.1177/0018726712453471

Bentler, P.M. (1990). Comparative fit indexes in structural models. Psychological Bulletin, 107(2), 238-246. http://dx.doi.org/10.1037/0033-2909.107.2.238

Bentler, P.M., \& Bonett, D.G. (1980). Significance tests and goodness of fit in the analysis of covariance structures. Psychological Bulletin, 88(3), 588-606. http:// dx.doi.org/10.1037/0033-2909.88.3.588

Berg, J.M., Wrzesniewski, A., \& Dutton, J.E. (2010). Perceiving and responding to challenges in job crafting at different ranks: When proactivity requires adaptivity. Journal of Organizational Behavior, 31(2-3), 158-186. http://dx.doi.org/10.1002/ job.645

Black, J.S., \& Ashford, S.J. (1995). Fitting in or making jobs fit: Factors affecting mode of adjustment for new hires. Human Relations, 48(4), 421-437. http://dx.dol. org/10.1177/001872679504800407

Brown, A., Charlwood, A., Forde, C., \& Spencer, D. (2007). Job quality and the economics of new labour: A critical appraisal using subjective survey data. Cambridge Journal of Economics, 31(6), 941-971. http://dx.doi.org/10.1093/cje/ bem028

Burchell, B., Sehnbruch, K., Piasna, A., \& Agloni, N. (2013). The quality of employment and decent work: Definitions, methodologies, and ongoing debates. Cambridg Journal of Economics, 38(2), 459-477. http://dx.doi.org/10.1093/cje/bet067

Cable, D.M., \& De Rue, D.S. (2002). The convergent and discriminant validity of subjective fit perceptions. Journal of Applied Psychology, 87(5), 875-887. http:// subjective fit perceptions. Journal of App
dx.doi.org/10.1037//0021-9010.87.5.875

Cumming, T.G., \& Cooper, C.L. (1979). A cybernetic framework for studying occupational stress. Human Relations, 32(5), 395-418. http://dx.doi. org/10.1177/001872677903200504

Deci, E.L., \& Ryan, R.M. (2000). The "what" and "why" of goal pursuits: Human needs and the self-determination of behaviour. Psychological Inquiry, 1(4), 227-268 http://dx.doi.org/10.1207/S15327965PLI1104_01

Demerouti, E., Bakker, A., Nachreiner, F., \& Schaufeli, W.B. (2001). The job demandsresources model of burnout. Journal of Applied Psychology, 86(3), 499-512. http://dx.doi.org/10.1037//0021-9010.86.3.499

Demerouti, E., \& Bakker, A.B. (2008). The Oldenburg burnout inventory: A good alternative to measure burnout and engagement. Handbook of stress and burnout in health care. Hauppauge, NY: Nova Science. Retrieved July, 2015, from http:// www.researchgate.net/profile/Arnold_Bakker/publication/46704152_The
Oldenburg_Burnout Inventory A good_alternative to measure_burnout_and Oldenburg_Burnout_Inventory_A__oood_alternative_
engagement/links $/ 5 \overline{3} \mathrm{f} 36 \mathrm{c} 060 \mathrm{cf} 2 \mathrm{~d} d 48950 \mathrm{cbd} 38 . \mathrm{pdf}$

Demerouti, E., Bakker, A.B., Vardakou, I., \& Kantas, A. (2003). The convergent validity of two burnout instruments: A multitrait-multimethod analysis. European Journa of Psychological Assessment, 19(1), 12-23. http://dx.doi.org/10.1027//1015of Psychological
5759.19 .1 .12

Demerouti, E., Mostert, K., \& Bakker, A.B. (2010). Burnout and work engagement: A thorough investigation of the independency of both constructs. Journal of

Dyląg, A., Jaworek, M., Karwowski, W., Kożusznik, M., \& Marek, T. (2013). Discrepancy between individual and organizational values: Occupational burnout and work engagement among white-collar workers. International Journal of Industrial Ergonomics, 43(3), 225-231. http://10.1016/j.ergon.2013.01.002

Edwards, J.R., Caplan, R.D., \& Harrison, R.V. (1998). Person-Environment fit theory: Conceptual foundations, empirical evidence, and directions for future research In C.L. Cooper (Ed.), Theories of organizational stress (pp. 28-67). Oxford, England: Oxford University Press.
Edwards, J.R., \& Shipp, A.J. (2007). The relationship between person-environment fit and outcomes: An integrative theoretical framework In C. Ostroff, T.A. Judge (Eds.), Perspectives on organizational fit (pp. 209-258). San Francisco, CA, JosseyBass. Retrieved July, 2015, from http://public.kenan-flagler.unc.edu/faculty/ edwardsj/EdwardsShipp2007.pdf

Edwards, J.R., \& Van Harrison, R.V. (1993). Job demands and worker health: Threedimensional re-examination of the relationship between person-environment fit and strain. Journal of Applied Psychology, 78(4), 628-648. http://dx.doi. org/10.1037/0021-9010.78.4.628

Gonzalez, R., \& Griffin, D. (2001). A statistical framework for modeling homogeneity and interdependence in groups. Blackwell handbook of social psychology: Interpersonal processes, 505-534. http://dx.doi.org/10.1002/9780470998557.ch20

Grant, A.M., \& Ashford, S.J. (2008). The dynamics of proactivity at work. Research in Organizational Behavior, 28, 3-34. http://dx.doi.org/10.1016/j.riob.2008.04.002

Greguras, G.J., \& Diefendorff, J.M. (2009). Different fits satisfy different needs: Linking person-environment fit to employee commitment and performance using selfdetermination theory. Journal of Applied Psychology, 94(2), 485-477. http://dx. doi.org/10.1037/a0014068

Hayes, A.F. (2009). Beyond Baron and Kenny: Statistical mediation analysis in the new millennium. Communication Monographs, 76(4), 408-420. http://dx.doi. org/10.1080/03637750903310360

Hu, L.T., \& Bentler, P.M. (1999). Cutoff criteria for fit indexes in covariance structure analysis: Conventional criteria versus new alternatives. Structural Equation Modeling: A Multidisciplinary Journal, 6(1), 1-55. http://dx.doi.org/10.1080/ 10705519909540118

Kämpfe, N., \& Mitte, K. (2009). What you wish is what you get? The meaning of individual variability in desired affect and affective discrepancy. Journal of Research in Personality, 43(3), 409-418. http://dx.doi.org/10.1016/j.jrp.2009.01.007

Kline, R. (2011). Principles and practice of structural equation modeling (3th edn.). New York: Guilford Press.

Körner, T., Puch, K., \& Wingerter, C. (2009). Quality of employment. Wiesbaden Federal Statistical Office of Germany.

Kristof-Brown, A.L., \& Billsbery, J. (Eds.). (2013). Organizational fit: Key issues and new directions. Malden, MA: Wiley-Blackwell.

Kristof-Brown, A.L., Zimmerman, R.D., \& Johnson, E.D. (2005). Consequences of individuals' fit at work: A meta-analysis of person-job, person-organization, person-group, and person-supervisor fit. Personnel Psychology, 58(2), 281-342. http://dx.doi.org/10.1111/j.1744-6570.2005.00672.x

Krumm, S., Grube, A., \& Hertel, G. (2013). No time for compromises: Age as a moderator of the relation between needs-supply fit and job satisfaction. European Journal of Work and Organizational Psychology, 22(5), 547-562. http://dx.doi.org /10.1080/1359432X.2012.676248

Landis, R.S., Beal, D.J., \& Tesluk, P.E. (2000). A comparison of approaches to forming composite measures in structural equation models. Organizational Research Methods, 3(2), 186-207. http://doi.org/10.1539/joh.M800210.1177/109442810 032003

Langelaan, S., Bakker, A.B., Van Doorne, L.J.P., \& Schaufeli, W.B. (2006). Burnout and work engagement: Do individual differences make a difference? Personality and Work engagement: Do individual differences make a difference? Personality and
Individual Differences, 40(3), 521-532. http://doi.org/10.1016/j.paid.2005.07.009

Lind, E.A. (2001). Fairness heuristic theory: Justice Judgments as pivotal cognitions in organizational relations. In J. Greenberg \& R. Cropanzano (Eds.), Advances in organizational justice (pp. 56-88). Stanford, CA: Stanford University Press.

Little, T.D. (2013). Specifying and interpreting a longitudinal panel model. In T. Little \& N. Card (Eds.), Longitudinal structural equation modelling (chap. 6, pp. 180-208). New York: Guilford.

Little, T.D., Cunningham, W.A., Shahar, G., \& Widaman, K.F. (2002). To parcel or not to parcel; exploring the question, weighing the merits. Structural Equation Modeling: A Multidisciplinary Journal, 9(2), 151-173. http://dx.doi.org/10.1207/ S15328007SEM0902_1

Little, T.D., Rhemtulla, M., Gibson, K., \& Schoemann, A.M. (2013). Why the items versus parcels controversy needn't be one. Psychological Methods, 18(3), 285-300. http://dx.doi.org/10.1037/a0033266

Lu, C.-Q., Wang, H.-J., Lu, J.-J., Du, D.-Y., \& Bakker, A.B. (2014). Does work engagement increase person-job fit? The role of job crafting and job insecurity. Journal of Vocational Behavior, 84(2), 142-152. http://dx.doi.org/10.1016/j.jvb.2013.12.004

Maslach, C., Jackson, S.E., \& Leiter, M.P. (1996). Maslach burnout inventory manual (3rd edn.). Palo Alto, CA: Consulting Psychologists Press.

Maslow, A. H. (1958). A Dynamic Theory of Human Motivation. In Stacey, Chalmers L. (Ed); DeMartino, Manfred (Ed), (1958). Understanding human motivation. (pp. 26-47). Cleveland, OH, US: Howard Allen Publishers, xv, 507 pp. http://dx.doi. org/10.1037/11305-004

Muñoz de Bustillo, R., Fernandez-Macias, E., Anton, J.I., \& Esteve, F. (2009). Indicators of job quality in the European Union. European Parliament's Committee of Employment and Social Affairs. Retrieved July, 2015, from http://www.europarl. europa.eu/activities/committes/studies.do?language $=E N$

Muthén, L.K., \& Muthén, B.O. (1998-2014). Mplus user's guide (7th edn.). Los Angeles, CA: Muthén \& Muthén.

OCDE (2012). Mal-être au travail, Mythes et réalités sur la santé mentale et l'emploi. Revue de l'OCDE, Bruxelles, Belgique.

Podsakoff, P.M., MacKenzie, S.B., \& Podsakoff, N.P. (2012). Sources of method bias in social science research and recommendations on how to control it. Annual Review of Psychology, 65, 539-569. http://dx.doi.org/10.1146/annurev-psych120710-100452 
Rich, B.L., Lepine, J.A., \& Crawford, E.R. (2010). Job engagement: Antecedents and effects on job performance. Academy of Management Journal, 53(3), 617-635. http://dx.doi.org/10.5465/AMJ.2010.51468988

Schaufeli, W.B., \& Bakker, A.B. (2004). Job demands, job resources, and their relationship with burnout and engagement: A multi-sample study. Journal of Organizational Behavior, 25(3), 293-315. http://dx.doi.org/10.1002/job.248

Schaufeli, W.B., Bakker, A.B., \& Salanova, M. (2006). The measurement of work Engagement with a short questionnaire: A cross-national study. Educational and PsychologicalMeasurement, 66(4), 701-716. http://dx.doi.org/10.1177/0013164 05282471

Securex (2014). Stress \& burn-out : menace pour les travailleurs... et les employeurs ? White-Paper, Securex 2014, Bruxelles, Belgium.

Seong, J.Y., \& Kristof-Brown, A.L. (2012). Testing multidimensional models of persongroup fit. Journal of Managerial Psychology, 27(6), 536-556. http://dx.doi. org/10.1108/026839412112524191

Steiger, J.H., \& Lind, J.C. (1980). Statistically based tests for the number of common factors. Paper presented at the Annual Spring Meeting of the Psychometric Society. April, 1980, lowa City, IA.

Tims, M., \& Bakker, A.B. (2010). Job crafting: Toward a new model of individual job redesign. SA Journal of Industrial Psychology, 36(2), 1-9. http://dx.doi. org/10.4102/sajip.v36i2.841

Tims, M., Bakker, A.B., \& Derks, D. (2012). Development and validation of the job crafting scale. Journal of Vocational Behavior, 80(1), 173-186. http://dx.doi. org/10.1016/j.jvb.2011.05.009

Tims, M., Bakker, A.B., \& Derks, D. (2013). The impact of job crafting on job demands, job resources and well-being. Journal of Occupational Health Psychology, 18(2), 230-240. http://dx.doi.org/10.1037/a0032141

Tims, M., Bakker, A.B., Derks, D., \& Van Rhenen, W. (2013). Job crafting at the team and individual level: Implications for work engagement and performance. Group \& Organization Management, 38(4), 427-454. http://dx.doi.org/ 10.1177/1059601113492421
Travaglianti, F., Babic, A., Pepermans, R., \& Hansez I. (in press). Needs-supplies fit and behavioural outcomes: The mediating role of organizational identification. Journal of Management and Organization.

Travaglianti, F., Orianne, J.F., Pichault, F., \& Hansez I. (2015). Construction d'une méthodologie exploratoire concernant les besoins des travailleurs: l'exemple des besoins de flexibilité au travail et de sécurité d'emploi des travailleurs à contrat permament. Revue Internationale de Psychosociologie et de Gestion des Comportements Organisationnels, 21(52), 147-162.

Van Aerden, K., Moors, G., Levecque, K., \& Vanroelen, C. (2015). The relationship between employment quality and work-related well-being in the European Labor Force. Journal of Vocational Behavior, 86, 66-76. http://dx.doi.org/10.1016/j. jvb.2014.11.001

Van Zyl, L.E., Deacon, E., \& Rothmann, S. (2010). Towards happiness: Experiences of work-role fit, meaningfulness and work engagement of industrial/organisational psychologists in South Africa. SA Journal of Industrial Psychology, 36(1), 1-10. Retrieved July, 2015, from http://www.scielo.org.za/scielo.php?script=sci_ arttext\&pid=S2071-07632010000100014\&lng=en\&tlng=en

Warr, P., \& Inceoglu, I. (2012). Job engagement, job satisfaction, and contrasting associations with person-job fit. Journal of occupational health psychology, 17(2), 129-138. http://dx.doi.org/10.1037/a0026859

Wrzesniewski, A., \& Dutton, J.E. (2001). Crafting a job: Revisioning employees as active crafters of their work. Academy of Management Review, 26(2), 179-201. http://dx.doi.org/10.5465/AMR.2001.4378011

Yu, K.Y.T. (2009). Affective influences in person-environment fit theory: Exploring the role of affect as both cause and outcome of PE fit. Journal of Applied Psychology, 94(5), 1210. http://dx.doi.org/10.1037/a0016403

Yu, K.Y.T. (2013). A motivational model of person-environment fit. In A.L. Kristof-Brown \& J. Billsbery (Eds.). Organizational fit: Key issues and new directions (pp. 99-123). Malden, MA: Wiley-Blackwell. 


\section{APPENDIX 1}

\begin{tabular}{|c|c|c|c|c|c|c|c|}
\hline \multicolumn{8}{|c|}{ S-NS Fit questionnaire } \\
\hline Ideally, I would like to... & $\begin{array}{c}-3 \\
\text { Far less } \\
\text { than now }\end{array}$ & $\begin{array}{c}-2 \\
\text { less than } \\
\text { now }\end{array}$ & $\begin{array}{c}-1 \\
\text { a bit less } \\
\text { than now }\end{array}$ & $\begin{array}{c}0 \\
\text { satisfied with } \\
\text { my current } \\
\text { state }\end{array}$ & $\begin{array}{c}1 \\
\text { a bit more } \\
\text { than now }\end{array}$ & $\begin{array}{c}2 \\
\text { more than } \\
\text { now }\end{array}$ & $\underset{\substack{3 \\
\text { far mowe }}}{\stackrel{3}{\text { non }}}$ \\
\hline Do a stimulating job & $\mathrm{O}$ & $\mathrm{O}$ & $\mathrm{O}$ & $\mathrm{O}$ & O & $\mathrm{O}$ & $\mathrm{O}$ \\
\hline Be versatile & $\mathrm{O}$ & $\mathrm{O}$ & $\mathrm{O}$ & $\mathrm{O}$ & $\mathrm{O}$ & $\mathrm{O}$ & $\mathrm{O}$ \\
\hline Be autonomous & $\mathrm{O}$ & O & $\mathrm{O}$ & O & $\mathrm{O}$ & $\mathrm{O}$ & $\mathrm{O}$ \\
\hline Balance my private life and my professional life & $\mathrm{O}$ & $\mathrm{O}$ & $\mathrm{O}$ & $\mathrm{O}$ & $\mathrm{O}$ & $\mathrm{O}$ & $\mathrm{O}$ \\
\hline Give priority to my private life & $\mathrm{O}$ & $\mathrm{O}$ & $\mathrm{O}$ & O & $\mathrm{O}$ & $\mathrm{O}$ & $\mathrm{O}$ \\
\hline Have working hours that allow me to manage my private life & $\mathrm{O}$ & $\mathrm{O}$ & $\mathrm{O}$ & $\mathrm{O}$ & $\mathrm{O}$ & $\mathrm{O}$ & O \\
\hline Have a predictable work schedule & $\mathrm{O}$ & O & $\mathrm{O}$ & O & $\mathrm{O}$ & O & $\mathrm{O}$ \\
\hline Choose my working hours & $\mathrm{O}$ & $\mathrm{O}$ & $\mathrm{O}$ & O & O & $\mathrm{O}$ & $\mathrm{O}$ \\
\hline Have a fixed work schedule & $\mathrm{O}$ & $\mathrm{O}$ & $\mathrm{O}$ & $\mathrm{O}$ & $\mathrm{O}$ & $\mathrm{O}$ & $\mathrm{O}$ \\
\hline Work from home & $\mathrm{O}$ & $\mathrm{O}$ & $\mathrm{O}$ & O & $\mathrm{O}$ & $\mathrm{O}$ & $\mathrm{O}$ \\
\hline Distance working & $\mathrm{O}$ & $\mathrm{O}$ & $\mathrm{O}$ & $\mathrm{O}$ & $\mathrm{O}$ & $\mathrm{O}$ & $\mathrm{O}$ \\
\hline Receive an individual performance based bonus & $\mathrm{O}$ & $\mathrm{O}$ & $\mathrm{O}$ & $\mathrm{O}$ & $\mathrm{O}$ & $\mathrm{O}$ & $\mathrm{O}$ \\
\hline Receive a group bonus based on the company's results & $\mathrm{O}$ & $\mathrm{O}$ & $\mathrm{O}$ & $\mathrm{O}$ & $\mathrm{O}$ & $\mathrm{O}$ & $\mathrm{O}$ \\
\hline Benefit from extras (luncheon vouchers, gift vouchers, etc.) & $\mathrm{O}$ & $\mathrm{O}$ & O & $\mathrm{O}$ & O & $\mathrm{O}$ & $\mathrm{O}$ \\
\hline Receive a fixed monthly income & $\mathrm{O}$ & $\mathrm{O}$ & $\mathrm{O}$ & $\mathrm{O}$ & $\mathrm{O}$ & $\mathrm{O}$ & O \\
\hline Receive income at a fixed date & $\mathrm{O}$ & $\mathrm{O}$ & $\mathrm{O}$ & O & $\mathrm{O}$ & $\mathrm{O}$ & $\mathrm{O}$ \\
\hline Receive enough income to cover my needs & $\mathrm{O}$ & $\mathrm{O}$ & $\mathrm{O}$ & $\mathrm{O}$ & $\mathrm{O}$ & $\mathrm{O}$ & $\mathrm{O}$ \\
\hline Follow training courses to extend my skills & $\mathrm{O}$ & $\mathrm{O}$ & $\mathrm{O}$ & $\mathrm{O}$ & $\mathrm{O}$ & $\mathrm{O}$ & $\mathrm{O}$ \\
\hline Follow training courses that correspond to my expectations & $\mathrm{O}$ & O & $\mathrm{O}$ & $\mathrm{O}$ & $\mathrm{O}$ & $\mathrm{O}$ & $\mathrm{O}$ \\
\hline Follow training courses to progress in my career & $\mathrm{O}$ & O & $\mathrm{O}$ & O & $\mathrm{O}$ & O & O \\
\hline Work in a successful company (profitability, size, reputation) & $\mathrm{O}$ & $\mathrm{O}$ & $\mathrm{O}$ & O & $\mathrm{O}$ & $\mathrm{O}$ & $\mathrm{O}$ \\
\hline Broad my chances of being able to get another job & $\mathrm{O}$ & $\mathrm{O}$ & $\mathrm{O}$ & $\mathrm{O}$ & $\mathrm{O}$ & $\mathrm{O}$ & $\mathrm{O}$ \\
\hline Work in an activity sector that has potential & $\mathrm{O}$ & O & $\mathrm{O}$ & O & $\mathrm{O}$ & $\mathrm{O}$ & $\mathrm{O}$ \\
\hline Have a stable work contract & $\mathrm{O}$ & $\mathrm{O}$ & $\mathrm{O}$ & $\mathrm{O}$ & $\mathrm{O}$ & $\mathrm{O}$ & $\mathrm{O}$ \\
\hline Have a contract that gives me an untroubled view of the future & $\mathrm{O}$ & $\mathrm{O}$ & $\mathrm{O}$ & O & $\mathrm{O}$ & $\mathrm{O}$ & $\mathrm{O}$ \\
\hline Be sure of a high income security in case of being fired/losing my job & $\mathrm{O}$ & $\mathrm{O}$ & $\mathrm{O}$ & O & O & $\mathrm{O}$ & $\mathrm{O}$ \\
\hline Know my social rights & $\mathrm{O}$ & $\mathrm{O}$ & $\mathrm{O}$ & $\mathrm{O}$ & $\mathrm{O}$ & $\mathrm{O}$ & $\mathrm{O}$ \\
\hline Enjoy acceptable physical working conditions & $\mathrm{O}$ & O & $\mathrm{O}$ & $\mathrm{O}$ & $\mathrm{O}$ & $\mathrm{O}$ & $\mathrm{O}$ \\
\hline Have a suitably organised workstation & $\mathrm{O}$ & $\mathrm{O}$ & $\mathrm{O}$ & $\mathrm{O}$ & $\mathrm{O}$ & $\mathrm{O}$ & $\mathrm{O}$ \\
\hline Have good working equipment & $\mathrm{O}$ & $\mathrm{O}$ & $\mathrm{O}$ & O & $\mathrm{O}$ & $\mathrm{O}$ & $\mathrm{O}$ \\
\hline Be recognised by my superiors & $\mathrm{O}$ & $\mathrm{O}$ & $\mathrm{O}$ & O & $\mathrm{O}$ & $\mathrm{O}$ & $\mathrm{O}$ \\
\hline Work in a positive atmosphere & $\mathrm{O}$ & O & $\mathrm{O}$ & O & $\mathrm{O}$ & O & $\mathrm{O}$ \\
\hline Be treated honestly and with respect & $\mathrm{O}$ & $\mathrm{O}$ & $\mathrm{O}$ & $\mathrm{O}$ & $\mathrm{O}$ & $\mathrm{O}$ & $\mathrm{O}$ \\
\hline Get on well with my superiors & $\mathrm{O}$ & $\mathrm{O}$ & $\mathrm{O}$ & $\mathrm{O}$ & $\mathrm{O}$ & $\mathrm{O}$ & $\mathrm{O}$ \\
\hline
\end{tabular}




\section{APPENDIX 2 S-NS Fit questionnaire development}

The S-NS Fit questionnaire focused on employment quality and was initially based on the literature as well as on 60 previous interviews (Travaglianti et al., 2015). These interviews aimed to highlight workers' needs in terms of employment quality by empirically testing the relevance of the indicators presented in the theoretical section of this paper (see Table 1). The interviews relied on questions such as, 'What is important for you in terms of employment quality?', 'How would you define a good job?' or 'What do you need most in your job?'. We finally distinguished 12 categories of specific work-related needs regarding employment quality, namely the need for: (1) a challenging job, (2) work-family balance, (3) a clear time schedule, (4) work flexibility, (5) regular financial reward, (6) personal development opportunities, (7) employability, (8) job security, (9) social protection, (10) a comfortable work environment, (11) fairness, and (12) recognition from the supervisor. The first ten categories translate the employment quality indicators provided by the literature into work-related needs and the last two are derived from the interviews. In order to create our questionnaire to measure S-NS Fit, we then created five items (based on workers' verbatim) for each work-related need. In total we ended up with a 60 item questionnaire. For each item, participants were asked to indicate their ideal state as compared to their present state on a sevenpoint scale from -3 (I would like much less than now) to +3 (I would like much more than now), with 0 (I am satisfied with my current state) as the middle value.

We pre-tested the newly created questionnaire on a previous sample $(N=250)$ and performed an exploratory factor analysis, with varimax rotation. After testing the multivariate normal distribution of the items (skewness and kurtosis), we also applied the Kaiser-Meyer-Olkin test and the Bartlett's test of sphericity on the correlation matrix. Twelve factors were then freely extracted from the data using the eigenvalue-method (we have retained the factors with an eigenvalue higher than 1 ). This resulted in a final questionnaire with 37 items distributed among 12 work-related needs factors (loadings cut-off: 0.50; Kline, 2011), namely the need for: a challenging job (3 items remain), work-family balance ( 3 items remain), a clear time schedule (3 items remain), work flexibility ( 3 items remain), additional rewards ( 3 items remain), regular financial rewards (3 items remain), personal development opportunities (3 items remain), employability (3 items remain), job security (3 items remain), social protection (3 items remain), a comfortable work environment (3 items remain), and fairness and recognition from the supervisor (4 items remain). As a result of this analysis, the initial need for a regular financial reward (highlighted through the interviews) was split into two different factors: the need for additional reward and the need for regular financial reward. Moreover, the need for fairness and the need for recognition (highlighted through the previous interviews) were merged into a single-factor: the need for fairness and recognition from the supervisor. Furthermore, and always following the chi-square difference tests proposed by Bentler and Bonett (1980), a confirmatory factor analysis (CFA) on the current sample, also showed that our 12 factors questionnaire presented better fit indices than other alternative models. Consequently, our 12 work-related needs factors were treated as independent variables (see Table 3 for an overview of our CFA results). This 37 item questionnaire has been already used in previous researches (e.g., Travaglianti et al., in press). 